\title{
Survey on the Present Status of Fish Species Diversity in a Stretch of Hooghly River and Inland Areas of Hooghly District of West Bengal, India
}

\author{
Ashim Kumar Nath* and Anindita Patra \\ Department of Zoology, Aquatic Ecology and Fisheries Laboratory, Department of Zoology \\ Sidho-Kanho-Birsha University, Purulia, West Bengal, India \\ *Corresponding author
}

\begin{abstract}
A B S T R A C T
Present investigation deals with the fish faunal diversity in different habitat types in Hooghly district. Three types of floodplain water bodies were studied such as river, canal and ponds to determine the distribution of different fish species during different seasons.

\begin{tabular}{|l|}
\hline Ke y w o r d s \\
Fish Species \\
Diversity, \\
Hooghly River. \\
\hline Article Info \\
\hline $\begin{array}{l}\text { Accepted: } \\
\text { 29 June 2017 } \\
\text { Available Online: } \\
\text { 10 July 2017 }\end{array}$ \\
\hline
\end{tabular}
Results exhibit presence of 87 species in river Hooghly, 57 species in inland water and 47 species in different canals. Seven (7) diversity indices and One (1) similarity index were calculated i.e., Simpson dominance index, Simpson diversity index, Margalef's richness index, Menhenick richness index, Shannon-Wiener diversity index, Maximum value of diversity index and Pielou's evenness index to describe the relationship between species number and their seasonal abundance. Dominance was maximum (0.0885) in monsoon season and minimum (0.0354) in post monsoon in different canals. The Shannon-Wiener diversity value ranged between $2-4$ and it has a parallel relationship with different species richness index. Post monsoonal catch represents highest species richness and species diversity in all habitats. Evenness index exhibit its highest value in monsoon both in river and canal whereas it reached maximum in post monsoon in ponds. Maximum similarity was observed between river and canals (0.6418) and minimum similarity (0.5833) was observed between ponds and canals. River and ponds showed moderate similarity (0.6153).
\end{abstract}

\section{Introduction}

The boundary of the Hooghly district is covered by the Hooghly river in the East, Bardhaman in the North, Howrah in the South, Paschim Medinipore in the West, Bankura in the North-West. Biodiversity represents trophic status of an aquatic system. It is very essential to have a sufficient knowledge about fish faunal diversity and their present status, because fish comprises the half of the total number of vertebrates in the world and they are the nutritional food source mainly the protein. According to their habitat types and food selection they have different nutritional food values. This investigation was carried out in 3 types of fish habitats i.e riverine water, canals and ponds to estimate and assess the total fish population in Hooghly District. Generally canals are connected to the Hooghly river through some small rivers such as Damodar, Saraswati etc. Adjoining areas of the Hooghly river represents a transitional zone between the typically estuarine conditions lower down and the purely freshwater stretch above. Large canals and canals in the paddy fields are mainly used for the spawning purposes of 
some of the fishes. On the other hand during monsoon sometimes ponds become over flooded by riverine water due to excessive rainfall and as a result mixing of different waters cause habitat change of the fishes. 'Tidal freshwater areas' included as a distinct part of an estuarine system (Fairbridge, 1980). The biota of tidal freshwater reaches of estuary experiences tidal fluctuations, without influence of salinity, so tidal freshwater reach of the estuary serves as a separate biotope with specific community structure. Literature reveals that these are important sites of physical, chemical and biological processes which may alter riverine input considerably before it reaches the freshwater-seawater interface (Schuchdart et al., 1997). The freshwater tidal stretches of the estuaries can be extensive, particularly in systems with high riverine input and these areas can support abundant fish and active fisheries (Odum, 1978).

Different authors described many fishes of the Ganga system including the Hooghly and its associated creeks (Hamilton, 1822; Annandale, 1922; Hora and Nair, 1940; David, 1954; Menon et al., 1972, Ghosh, 2008). As for the fishes concerned, they are grouped as residents and transient; the former being present in estuarine waters or fresh water areas throughout the year in some or all size groups and the transients enter and remain in one or more zones for short duration. Up to 1935 , the maximum salinity at Palta was less than $0.25 \mathrm{~g} / \mathrm{l}$ (potable limit) and since 1936 it has started rising and in 1966 the maximum salinity at the intake became $3 \mathrm{~g} / \mathrm{l}$. During post Farakka barrage salinity recorded from nil from Nurpur (24 Parganas South) to upstream.

Vishwakarma et al., (2014) investigated the fish fauna in Narmada basin and documented total 33 species belonging 9 families. Mishra et al., (2011) also enlisted 62 species belonging 24 families after examination of fish diversity of Gangetic basin of Northern India. Vijayalaxmi and Vijaykumar (2014) found total 29 fish species in Bheema river in Karnataka.

No comprehensive studies have been conducted comparing the fish species availability in Hooghly river, canals and ponds of the Hooghly district of West Bengal. Present study aims a detailed analysis of fish of the fish community structure, endemism and species richness in the freshwater zone of the Hooghly estuary including canals and ponds of Hooghly district of West Bengal by studying gear wise fish catch diversity. It will also be used to assess the present fish status as well as the health of the aquatic ecosystem.

\section{Materials and Methods}

Fish samples were collected throughout two years (March, 2013-February, 2015) by different gears i.e Set barriers, Bachhadi net, Cast net, Vesal net, line and hooks. Study was done in three different habitats i.e. through a stretch Hooghly river from Serampore (Dist Hooghly) (N $22^{\circ} 45.803^{\prime}$ E $088^{\circ} 20.879^{\prime}$ ) to Tribeni (Dist. Hooghly) (N $22^{\circ} 59.728^{\prime}$ E $\left.088^{\circ} 24.525\right)$ during full moon and new moon period, in different canals (DVC) and different ponds (Singur, Dhaniakhali and Jirat). To investigate the seasonal variation of fish communities this study period is categorized into 3 phases viz. pre monsoon (March-June) with little or no rainfall with very high temperature, the monsoon (JulyOct) with heavy rainfall and relatively lower temperature and post monsoon (Nov-Feb) season with a drastic reduction of temperature and occasional rainfall. Mainly Behundi net (mesh size $15 \mathrm{~mm}$ near the mouth to $5 \mathrm{~mm}$ at the end), Bachhadi net (mesh size $15 \mathrm{~mm}$ ), Cast net (mesh size $8-20 \mathrm{~mm}$ ), Set barriers (mosquito net) are used for fishing in all sampling sites but there are some devices like 
line and hooks which are operated to catch specific types of fish species by local fishermen. Fish specimens which are sampled seasonally were identified by taxonomic characterization and preserved in 5\% formalin solution for further study. The classification of fishes adopted following Nelson (1994).

Different diversity index were assessed to understand the biodiversity status of fish in three habitat types. Different diversity index are also used to describe the relationship between species number and their seasonal abundance. Seven (7) diversity indices and one (1) similarity index were calculated i.e Simpson dominance index, Simpson diversity index, Margalef's richness index, Menhenick richness index, Shannon-Wiener diversity index, Maximum value of diversity index and Pielou's evenness index. Similarity index was Sorenson's similarity index.

\section{Results and Discussion}

Total 87 species belonging 12 orders were observed and enlisted in riverine water. Total 57 species were found in inland waters (ponds) whereas 47 species were observed in different canals. Result shows highly post monsoonal catch both in river canals as well as inland water bodies. Some species which are typically marine species were found in Darakeswar river during monsoon. Catches are mainly dominated by Amblypharyngodon mola, Channa punctatus, Puntius conchonius, Puntius sophore, Mystus vittatus, Mystus cavasius, Glossogobius giuris both in canals and ponds throughout all seasons but they varied in their abundance season to season. Glossogobius giuris, Pseudapocryptes lanceolatus, Odontamblyopus rubicundus, Ailia coilia, Clupisoma garua, Tenualosa ilisha, Setipinna phasa were found in large numbers and form a major portion of the catch. Sicamugil cascasia was observed first only in Damodar river in very small amount during post monsoon. Pseudambasis lalhia which was observed in pre monsoon and post mosson exhibit their high abundance in post monsoonal catch. This documentation shows presence of a riverine species Eutropichthys vacha which was catched from DVC canal of Hooghly in a voluminous amount during monsoon. Mystus gulio and Neotropius atherinoides were observed in different canals during post monsoon but they showed their abundance in very small amount. Notopterus notopterus was found throughout all the season whereas Notopterus chitala was observed only in monsoon. Amphipnous cuchia was observed only in monsoon season. Coloured Trichogaster fasciatus was found only in inland water bodies and their highest abundance was observed in monsoon. Heteropneustes fossilis, Clarias gariepinus, Clarias batrachus appeared very abundantly during starting of premonsoon season when the water level is normally lower than the other seasons, because reduced water level is very suitable for their growth and their survival. In different canal systems catch represents highest fish species diversity as well as their abundance in post monsoon followed by pre monsoon and monsoon. Post monsoonal assemblage of species is mainly dominated by Channa punctatus, Amblypharyngodon mola, Puntius conchonius and Puntius sophore both in canals and in different ponds. Puntius conchonius, Puntius sophore, Puntius ticto were observed in ponds whereas in canals only Puntius conchonius and Puntius sophore were present. Tetradon cutcutia was found in riverine water and canal water.

Overall estimations of results indicate the variation in species diversity indices (Table 1) as well as species existence due to difference in their habitat types. In the assessment of the fish community of different canals during the entire study period dominance was maximum $(0.0885)$ in monsoon season and minimum 
(0.0354) in post monsoon. According to this index when it increases diversity decreases and it varies from 0 to 1 . Dominance value of 1 represents zero diversity of the community which is occupied by only one species. Similarly, Dominance index of river and ponds show their maximum value in monsoon and minimum value in post monsoon due to high abundance of some specific species which mainly occupied the entire community. Simpson diversity index exhibits inverse proportion to the dominance value in all three types of habitat. This index ranges from 0.6 to 0.9 in stable community (Dash, 2003) and under stressed condition i.e. when only one or two species dominate whole community this index show near the zero value due to very low species diversity. The Shannon-Wiener diversity value ranges between $2-4$ and it has a parallel relationship with different species richness index. As species richness increases species diversity increases. Post monsoonal catch represents highest species richness and species diversity in all habitats. This is due to presence of most diversed community in post monsoon because of heavy raining and flood which causes the mixing of water from different water bodies. Besides during monsoon heavy rainfall causes entry of marine water with some typically marine species into the estuarine water system and they utilize this habitat for their breeding and spawning purpose. On that basis overall investigation represents the highest value of diversity and richness in post monsoonal catch. According to the Shannon-Wieiner diversity index, less than 1 indicates heavy pollution with stressed community, value between 1-2 represents moderate stability and above 3 signifies stable and healthy environment for their survival (Stub. et al 1970). Thus it can be interpreted that post monsoonal community of all habitat represent very mature and stable water environment. Margalef's index ranges from 1.8 to 6.7 in river, 1.9 to 4.9 in canal system and 3.8 to 6.4 in inland waters but significantly higher values were observed in during post monsoon both in river and inland water due to presence of large number of species. Margalef's richness index is used to compare the richness value of different community mainly based on the deviation of species numbers (Vyas et al., 2012). $H_{\max }$ represents the maximum value of Shannon-Wieiner diversity index i.e $\mathrm{H}^{\prime}$ reaches maximum when all species are occupied by same number of individuals. Evenness index exhibit its highest value in monsoon both in river and canal whereas it reached maximum in post monsoon in ponds. According to Magurran (1988), species diversity is comprised of two components i.e, species richness (number of species present in a community) and species evenness (the relative abundance of the distribution of species). He also opined that higher evenness in an assemblage reveals that maximum species are equally abundant. Evenness expresses the distribution of the individuals over the different species more evenly (Heip et al., 1998). The Sorenson's similarity index between different water systems was done to determine the similar species present in different water bodies. This index expresses how many species are distributed commonly in different habitats. Maximum similarity was observed between river and canals (0.6418) and minimum similarity (0.5833) was observed between ponds and canals. River and ponds showed moderate similarity (0.6153). This indicates uncommon or dissimilar species present in all three study sites (rivers, canals and ponds).

Most commonly used indices are Shannon diversity index and Simpson's dominance index which have an inverse relationship in between them. Though Simpson's index is calculated to assess the dominance and diversity, it fails to express the species richness value. 
Table.1 Different indices of River, Canals and ponds

River:

\begin{tabular}{|l|l|l|l|l|l|l|l|}
\hline & $\begin{array}{l}\text { Simpson } \\
\text { dominance } \\
\text { index (C) }\end{array}$ & $\begin{array}{l}\text { Simpson } \\
\text { diversity } \\
\text { index } \\
(\mathrm{D})\end{array}$ & $\begin{array}{l}\text { Margalef's } \\
\text { richness } \\
\text { index (R) }\end{array}$ & $\begin{array}{l}\text { Menhanick's } \\
\text { richness } \\
\text { index }\left(\mathrm{D}_{\mathrm{Mn}}\right)\end{array}$ & $\begin{array}{l}\text { Shannon- } \\
\text { wiener } \\
\text { diversity } \\
\text { index } \\
\left(\mathrm{H}^{\prime}\right)\end{array}$ & $\mathrm{H}_{\max }$ & $\begin{array}{l}\text { Evenness } \\
\text { index }(\mathrm{J})\end{array}$ \\
\hline Premonsoon & 0.0552 & 0.9448 & 3.719 & 0.6724 & 3.0801 & 4.858 & 0.6340 \\
\hline Monsoon & 0.0908 & 0.9092 & 1.855 & 0.7416 & 2.398 & 3.46 & 0.6930 \\
\hline Postmonsoon & 0.0319 & 0.9681 & 6.768 & 0.9632 & 3.694 & 5.8073 & 0.6361 \\
\hline
\end{tabular}

Canals:

\begin{tabular}{|l|l|l|l|l|l|l|l|}
\hline & $\begin{array}{l}\text { Simpson } \\
\text { dominance } \\
\text { index (C) }\end{array}$ & $\begin{array}{l}\text { Simpson } \\
\text { diversity } \\
\text { index } \\
(\mathrm{D})\end{array}$ & $\begin{array}{l}\text { Margalef's } \\
\text { richness } \\
\text { index }(\mathrm{R})\end{array}$ & $\begin{array}{l}\text { Menhanick's } \\
\text { richness } \\
\text { index }\left(\mathrm{D}_{\mathrm{Mn}}\right)\end{array}$ & $\begin{array}{l}\text { Shannon- } \\
\text { wiener } \\
\text { diversity } \\
\text { index } \\
\left(\mathrm{H}^{\prime}\right)\end{array}$ & $\mathrm{H}_{\max }$ & $\begin{array}{l}\text { Evenness } \\
\text { index }(\mathrm{J})\end{array}$ \\
\hline Premonsoon & 0.0678 & 0.9322 & 2.72 & 0.7893 & 2.788 & 4.17 & 0.6686 \\
\hline Monsoon & 0.0885 & 0.9115 & 1.978 & 0.7442 & 2.4582 & 3.585 & 0.6857 \\
\hline Postmonsoon & 0.0354 & 0.9646 & 4.96 & 1.057 & 3.4542 & 5.17 & 0.6681 \\
\hline
\end{tabular}

Inland waters:

\begin{tabular}{|l|l|l|l|l|l|l|l|}
\hline & $\begin{array}{l}\text { Simpson } \\
\text { dominance } \\
\text { index (C) }\end{array}$ & $\begin{array}{l}\text { Simpson } \\
\text { diversity } \\
\text { index } \\
(\mathrm{D})\end{array}$ & $\begin{array}{l}\text { Margalef's } \\
\text { richness } \\
\text { index }(\mathrm{R})\end{array}$ & $\begin{array}{l}\text { Menhanick's } \\
\text { richness } \\
\text { index }\left(\mathrm{D}_{\mathrm{Mn}}\right)\end{array}$ & $\begin{array}{l}\text { Shannon- } \\
\text { wiener } \\
\text { diversity } \\
\text { index } \\
\left(\mathrm{H}^{\prime}\right)\end{array}$ & $\mathrm{H}_{\max }$ & $\begin{array}{l}\text { Evenness } \\
\text { index }(\mathrm{J})\end{array}$ \\
\hline Premonsoon & 0.0377 & 0.9623 & 4.133 & 0.8226 & 3.3025 & 4.954 & 0.6666 \\
\hline Monsoon & 0.0421 & 0.9579 & 3.845 & 0.8366 & 3.222 & 4.8073 & 0.6702 \\
\hline Postmonsoon & 0.0028 & 0.9972 & 6.43 & 1.107 & 3.7982 & 5.6438 & 0.6729 \\
\hline
\end{tabular}

Similarity index:

\begin{tabular}{|l|l|l|l|}
\hline & River and Canal & River and Ponds & Canal and Ponds \\
\hline $\begin{array}{l}\text { Sorenson's similarity } \\
\text { index }\end{array}$ & 0.6418 & 0.5833 & 0.61538 \\
\hline Dissimilarity index & 0.3582 & 0.4167 & 0.38462 \\
\hline
\end{tabular}

Results from different indices it is clear that diversity indices are able to determine an ecosystem status but it fails to recognize the rarest species which is most important factor of conservation. Therefore continuous documentation of fish fauna is very essential to recover the degraded water ecosystem. According to Magurran (1988) when dominance increases evenness decreases as they have an antagonistic relationship in between them, but they always do not follow the same trend. Thus indices can give only the quantitative estimation which cannot fulfill the overall investigation to assess the status of fish.

Determination of biodiversity has become very essential aspect to understand and 
express the condition of an ecosystem. This investigation was done to estimate the fish assemblage in three types of water habitat and their distribution during different seasons. Documentation revealed the decreasing fish faunal assemblage year after year because of habitat degradation as well as destruction of water ecosystems. Besides, overfishing seriously affects fish abundance which ultimately destroys the species diversity. Fish faunal documentation has become very important issue under destructive as well as changing water environment. Data collection and fish identification are main keys to understand the present status of fish which helps to take the fruitful strategies for their sustainable development and conservation in future.

\section{Acknowledgement}

Authors are grateful to West Bengal Biodiversity Board for providing fund to carry out this work and to the Principal, Serampore College for giving permission to do the work.

\section{References}

Annandale, N. 1922. The Marine Element in the Fauna of Ganges, Bijdragen tot teDierkunde, 22, Feest number Dr. Max Weber.

Dash, M.C. 2003. Fundamental of Ecology. 2nd Edition Tata McGraw-Hill publishing company limited, New Delhi.

David, A. 1954. A preliminary survey of the fish and fisheries of a five mile stretch of the Hooghly river near Barrackpore. Indian J. Fish, 1(1and 2): 231-255.

Fairbridge, R.W. 1980. The estuary, its definition and geological role. In: E. Ollausson and I. Cato (Eds) Chemistry and Geochemistry of Estuaries, John Wiley. New York. 1-5.
Ghosh, A. 2008. Present Status of fish diversity in a $12 \mathrm{~km}$ stretch in the freshwater zone of the Hooghly estusry. J. Inland Fish Soc. India, 40 (spl.1): 6066.

Hamilton, B. 1822. An Account of the Fishes from the River Ganges and Its Branches (Edinburgh).

Heip, C.H.R., Herman, P.M.J. and Soetaert, K. 1998. Indices of diversity and evenness. Oceanis, 24: 61-87.

Hora, S.L. and Nair, K.K. 1940. Further observations on the Bionomics and Fishery of the Indian Shad, Hilsa ilisha (Hamilton) in Bengal Waters. Rec. Ind. Mus., 42: 35-50.

Magurran, A.E. 1988. Ecological diversity and its measurement. Prenceton University Press. Princeton.

Margalef, R. 1951. Diersidad de species en las comunidales naturals. Publ. Inst. Bio. Appl., 9: 5-27.

Menhinick, E.P. 1964. A comparison of some species - Individuals diversity indices applied to samples of field insects. Ecol., 45: 859-881.

Menon, A.G.K., Rama Rao, K.V. and Sen, T.K. 1972. The Hooghly and its fisheries in the past, the present and the future with special reference to the Farakka barrage on the Ganga. Sci. Cult., 38(8): 338-343.

Mishra, S.K., Sarkar, U.K., Gupta, B.K., Trivedi, S.P., Dubey, V.K. and Pal, A. 2011. Pattern of freshwater fish diversity, Threats and issues of fisheries management in an unexplored tributary of the Ganges basin, Northern India. $J$. Ecophysiol. Occup. Hlth., 11: 149-159.

Nelson, J.S. 1994. Fishes of the world. John Wiley and Sons. New York. USA, 599.

Odum, W.E. 1978. The importance of tidal freshwater wetlands in coastal zone management, Coastal Zone'78. American Society of Civil Engineers, New York. 
Pielou, E.C. 1966. The measurement of diversity in different types of biological collections. J. Theor. Biol., 13: 131-144.

Schuchdart, B.U., Haesloop, U., Schirmer, I.M. 1997. The tidal freshwater reach of the Weser estuary. Riverine or Estuarine? Aquatic Ecol., 27(2-40): 215-226.

Shannon, C.E. and Wiener, W. 1963. The Mathematical Theory of Communication. University of Illinois Press, Urbana, Illinois.

Simpson, E.H. 1949. Measurement of diversity. Nature, 163: 688.

Sorenson, T. 1948. A method of establishing groups of equal amplitude on similarity of species content. Biologiske Skrifter K. Danske Videnskbernes Selskab, 5(4): $1-34$.

Staub, R., J.W., Appling, A.M., Hofsteiler and Hass, I.J. 1970. The effects of industrial wastes on Memphis and shelby county on primary planktonic producers. Biosci., 20: 905-912.

Vijaylaxmi, C. and Vijaykumar, K. 2011. Biodiversity of Fish Fauna of The Bheema River in Gulbarga district in Karnataka. The Ecoscan, 5(1\&2): 2125.

Vishwakarma, K.S., Mir, A.A., Bhawsar, A. and Vyas, V. 2014. Assessment of Fish assemblage and distribution in Barna Stream Network in Narmada basin (Central India). Int. J. Adv. Res., 2(1): 888-897.

Vyas, V., Damde, D. and Parashar, V. 2012. Fish Biodiversity of Betwa River in Madhya Pradesh, India with Special reference to Sacred Ghat. Int. J. Biodiv. Con., 4(2): 71-77.

\section{How to cite this article:}

Ashim Kumar Nath and Anindita Patra. 2017. Survey on the Present Status of Fish Species Diversity in a Stretch of Hooghly River and Inland Areas of Hooghly District of West Bengal, India. Int.J.Curr.Microbiol.App.Sci. 6(7): 4260-4266.

doi: https://doi.org/10.20546/ijcmas.2017.607.441 